\title{
Alternative Settlement Through The Administrative Court By Testing The Authority Of Law Enforcement Procedures In The Order To Minimize Miscarriage of Justice
}

\author{
Bagus Oktafian Abrianto ${ }^{1}$, Sigmawati Widyaningrum ${ }^{1}$, Khofifah Nura Adila ${ }^{1}$, Andrean \\ Gregorius Pandapotan ${ }^{1}$, Wahyu Aliansa ${ }^{1}$ \\ bagusoa@fh.unair.ac.id, sigmawati.widyaningrum-2018@fh.unair.ac.id, khofifah.nura.adila- \\ 2018@fh.unair.ac.id \\ ${ }^{1}$ Universitas Airlangga, Indonesia
}

\begin{abstract}
A court decision should be a means for judges to realize justice. In fact, it is not uncommon for court decisions to contain a Miscarriage of Justice which is a failure to achieve a justice. Miscarriage of justice occurs in the criminal justice process where if the judge makes a decision that occurs in someone who is not guilty or has not committed a crime, but is processed or even sentenced to criminal through a law enforcement process that directs the person as a criminal. The occurrence of miscarriage of justice should be minimized. Therefore, the legal issues that will be raised in this research include (1) the nature of miscarriage of justice in the criminal justice system; (2) the nature of the Administrative Court's authority in examining the actions of law enforcement officers who have the potential to commit Miscarriage of Justice. The purpose of this paper is to analyze the nature of miscarriages of justice in the criminal justice system and to analyze the authority of the Administrative Court in examining the actions of law enforcement officials who have the potential to commit miscarriages of justice. The method used in this research is legal research with doctrinal research type. The approaches used in this research are statute approach, theoretical approach, and comparative approach. To minimize miscarriage of justice itself, it can be done with an administrative law approach as Primum Remedium through testing the authority of law enforcement officials at the Administrative Court.
\end{abstract}

Keywords: Court Decision; Miscarriage of Justice; Primum Remedium; Administrative Court.

\section{Introduction}

Judges are called noble professions because they have the authority to give court decisions regarding whether a person is guilty or not. A judge has an important role and position in law enforcement in addition to the police, prosecutors, and advocates. In the context of criminal procedural law, a court decision is a judge's statement in the form of a conviction or acquittal or acquittal of all lawsuits pronounced in a court session open to the public. [1] The implementation of the judiciary which is carried out openly to the public is the determining element of a judge's decision which is considered valid and has legal force in addition to the existence of 2 (two) valid pieces of evidence. Court decisions are a means for judges to achieve justice. If there are statutory provisions that are used as the basis for giving decisions that are not in accordance with the times and demands for a sense of justice, or if the law does not regulate, then the judge must explore the legal values and sense of justice that live in society. 
[2] Therefore, judges are expected to be able to give decisions that fulfill a sense of justice in the context of law enforcement in court.

However, not all decisions issued by judges fulfill a sense of justice. It is not uncommon for judges to issue decisions containing a Miscarriage of Justice. Cases of judges' decisions containing miscarriages of justice often occur in law enforcement in Indonesia. The definition of miscarriage of justice according to the Merriam Webster Dictionary is an error from an unfair judicial process that results in a person who should not be guilty of being convicted or a person who is guilty of being acquitted from prosecution. [3] Miscarriage of justice occurs in the criminal justice process because judges do not carry out law enforcement properly. One of the most popular cases of miscarriage of justice in Indonesia is the Sengkon and Karta trials.

The occurrence of miscarriages of justice must be minimized from the law enforcement system. The efforts that can be made to minimize or even eliminate miscarriages of justice are through alternative settlements in the Administrative Court. Therefore, the legal issues described in the study include:

1) The Nature of the Miscarriage of Justice in the criminal justice system;

2) the nature of the Administrative Court's authority in examining the actions of law enforcement officers who have the potential to commit Miscarriage of Justice.

\section{Methods}

The method used in this research is normative legal research by assessing applicable laws and regulations or references related to miscarriages and the authority of the Administrative Court in resolving cases of miscarriage. Normative legal research is also called doctrinal research because the object of study examined in this research is the document of legislation and references. The approaches used in this research are the legal approach, the theoretical approach, and the comparative approach.

\section{Result and Discussion}

\section{The Nature of Miscarriage of Justice in The Criminal Justice System}

Indonesia is a country that adheres to the Civil Law System, which has three main characteristics, they are (1) The codification of laws and regulations; (2) The judicial system is inquisitorial; and (3) The main legal source is legislation. Unlike the common law system countries, they use jurisprudence as the main basis for judges in deciding a case. However, it does not mean that judges in the Civil Law System are seen as mouthpieces of the law, but as a harmonic between legislation and the objectives of the law itself, namely justice and legal certainty.

Aristotele didn't mention that the purpose of law is order. That is because Aristotle saw the reality that humans are naturally social creatures, so that no matter how small a unit of community life, still humans live in groups. In life such life is not order that becomes a problem of community life, but fairness of allocation of interests in community life. [4] The purpose of law other than justice is legal certainty. In the Civil Law System itself the existence of legal certainty the main benchmark. Life in society, there is need for a general rule. However much the interests that exist in society considered to be set forth in general rules so that those interests are protected and as democratic as any state and society of a nation, it is impossible that these rules can accommodate all these interests. Similarly, in real life unique cases are rare, which occur are common problems arising from the existence of interests to be served. [4] These rules as guidelines and limitations of individuals living in society. 
After the amendment of 1945 Constitution in Article 1 paragraph 3, the state of Indonesia is a rule of law. It means that Indonesia places the law as the basis of state power and the implementation of that power in all its forms is carried out under the rule of law. [5] The rule of law is a country that stands on the law that guarantees justice to its citizens. Justice is a prerequisite for the achievement of happiness or welfare of life for citizens and from that justice needs to be taught morality to every human being so that he becomes a good citizen. [6]

L.J van Apeldoorn in his work Inleiding tot de Studie van het Nederlandse Recht mentions that antinomy between justice and legal certainty. He said the two objectives of the law cannot be realized together. In principle, both of these things can be applied at the same time. Various aspects of the purpose of legal certainty will equip law enforcement to provide appropriate legal considerations. Especially judges who act as an extension of God's hand in formulating a verdict. Lawmakers in formulating legal norms must dig into the values and needs of society. The representation of the legislature as a representative of the people should play an important role in this regard. However, what often happens is that the laws and regulations are like a political contract. Authority as a lawmaker is abused for the benefit of certain individuals and groups.

The circumstances of failure to realize the purpose of the law led to miscarriage of justice. According to Black's Law Dictionary, the definition of miscarriage of justice is "A grossly unfair outcome in a judicial proceeding as when a defendant is convicted despite a lack of evidence on an essential element of the crime also termed failure of justice." According to O.C. Kaligis called the miscarriage of justice is a situation where law enforcement who has the power and authority to strive for justice, it turns out to use the power and authority that is in it precisely to give injustice. [7] Talking about law enforcement can't be separated from the judicial institutions that have the task of seeking justice. Supposedly, Judges are obliged to avoid mistakes in making decisions or ignore facts that can ensnare the accused or the parties or deliberately make considerations that benefit the defendant or the parties in trying a case he is handling. The outcome in a case is very dependent on the considerations issued by the judge included in the decision. Duties and functions of judges are not always to decide, the most important function of judges in resolving legal issues is by giving peace to the parties seeking justice, as the provisions in Article $130 \mathrm{HIR} / 154 \mathrm{RBg}$ require the judges to reconcile the parties litigate in a civil dispute. [6]

Miscarriage of Justice is not only due to a ruling that has permanent legal force. But at the stage of research, investigation, trial stage and at the stage of legal efforts. Clive Walker in this case formulated several factors causing miscarriage of justice that occurred in suspects, defendants or convicts, namely (1) insufficient legal proceedings; (2) The law applied to them; (3) There is no justification for the punishment given; (4) The treatment of suspects, defendants or convicts is not balanced with the rights of others to be protected; (5) When the rights of others are not actively protected by the state from the perpetrators of the crime; (6) The laws applicable in the country itself. [8] Another factor that led to the Miscarriage of Justice was that the Law had been converted into a tool of power. [9] The crisis of professional spirituality causes law enforcement to lose a culture or culture of right doing consisting of four principles: (1) integrity; (2) the dignity of all human beings surrounded by civilization; (3) Perfection; And (4) sympathy. [10] Only by the existence of these four key principles is the law enforcement profession lived as a vocation, or often called "trust", as well as underpinning the existence of "professional privilege" attached to the law enforcement profession. [9]

The state provides some facilities to victims in the event of a Miscarriage of Justice. As in forced efforts on the investigation process suspects can file pretrial legal efforts. Meanwhile, if there is a Miscarriage of Justice in the court's decision that has inkracht van 
gewijsde, the state provides legal efforts in the form of extraordinary legal efforts review (PK). Based on article 263-268 kuhap provides opportunities to convicts or heirs who are victims of miscarriage of justice. The right to apply for pk is not given to the state represented by the Indonesian Prosecutor's Office, because the state has never been a victim of miscarriage of justice. The state is the party that commits acts of miscarriage of justice against its citizens. This is also strictly regulated in the KUHAP. The rights of convicts or their heirs are reaffirmed in the Decree of the Minister of Justice of the Republic of Indonesia Number: M.01. PW.07.03 of 1982 on Guidelines for the Implementation of KUHAP.

Facilities that have been provided by the state in the form of legal efforts are felt less because in this case the problem is not just fallacy in giving legal consideration. But also the human resources of law enforcement itself as revealed by Kenneth W Starr that the crisis of professional spirituality causes law enforcement to lose a culture or culture of doing right. Therefore, it takes an institution to handle judicial officials who are considered the mastermind of the miscarriage of justice in order to minimize the occurrence of Miscarriage of Justice.

\section{The Nature of The Administrative Court's Authority in Examining The Actions of Law Enforcement Officers who have The Potential to Commit Miscarriage of Justice}

The judgement is the nature of the judiciary, the core and purpose of any judicial activity or process, which contains the resolution of cases that since the process began have burdened the parties. From a series of judicial processes, none outside the judicial decision can determine the rights of one party and the burden of obligations on the other party, the validity of an act according to the law and laying down the obligation to be carried out by the parties required in the case. Between the stages in the judicial process (investigation, prosecution, examination, and execution), the execution process with the delivery of the verdict by the judge gives great influence to the parties. [11] The judge's decision determines the fate of the parties regarding the statement of punishment and release. Not infrequently, judges give misguided verdicts that give rise to people who should not be guilty become convicted or guilty people become free from lawsuits.

As public law, administrative law is based on the principles of state law (rechtsstaat), democratic principles and in accordance with the basic concept of administrative law as a juridical instrument (juridische instrumenten), administrative law also contains instrumental characters. The principle of state law is concerned with guaranteeing legal protection against governmental power. The principle of democracy itself is related to procedures and substance in the administration of government, both in the form of decision-making and in the form of concrete actions. The instrumental principle is concerned with the achievement of government objectives. The enactment of Law No. 30 of 2014 on Government Administration (Government Administration Law) reformed administrative law which became the first law that regulates the implementation of government to be more in accordance with the expectations and needs of the community and as a foundation and guideline for government bodies and or officials. This Government Administration Law regulates the legal relationship between the body or administrative officials of the government and the community in the public jurisdiction. In addition, it also sets limits and rules that contain obligations and rights between the body or administrative officials of government and the community. A lawsuit against violations of the provisions of this law can be filed with the Administrative Court With event law based on Law No. 5 of 1986 on State Administrative Justice jo. Law No. 9 of 2004 on Amendments to Law No. 5 of 1986 on State Administrative Justice jo. Law No. 51 of 2009 on Second Amendment to Law No. 5 of 1986 on State Administrative Justice. Based on article 47 of Law No. 5 of 1986 concerning the Administrative Court, the Administrative Court has the authority to examine, 
resolve and resolve disputes of state governance by state officials or administrative entities both at the central level and in the area. This authority develops in line with the practice of government administration which is also increasingly widespread and the emergence of state institutions that support the implementation of government. The issues reviewed by the First Administrative Court on the authority of the Administrative Court and the second the expansion of the object of dispute that can be tried by the Administrative Court after the issuance of Law No. 30 of 2014 on government administration. The object of the dispute of the Administrative Court is the State Administrative Decision. The scope of the source of the issuance of State Administrative Decisions that have the potential to become a dispute in the Administrative Court is also increasingly broad as mentioned in Article 87 of the Government Administration Act, the Decision of the Agency and/or The State Administrative Officer of the executive, legislative, judicial, and other state organizers. While the Administrative Court Act still contains a more rigid and narrow concept.

One form of judicial supervision is by administrative justice through the mechanism of a lawsuit by a person or entity of civil law. In essence, it is no different from the task of the judiciary in general, which is to maintain material law in this case material administrative law. The Explanation of the Administrative Justice Act calls it a means of resolving disputes between the state administration and the people. From other aspects are also referred to as a means of maintaining that the implementation of government by government officials is always based and according to the law.

The expansion of the Administrative Decision as in article 87 of the Administrative Act of government, gives the victims of miscarriage of justice the opportunity to make legal efforts to the Administrative Court. Given that miscarriage of justice is not only due to fallacy in giving legal consideration but also human resources from law enforcement itself as expressed by Kenneth W Starr who called it by the term crisis of professional spirituality, filing a lawsuit to the Administrative Court can be an alternative step. It is also in line with the principle of administrative law as Primum Remedium.

\section{Conclusion}

Basically, Miscarriage of Justice is not only caused by a judge's decision that results in a person who should not be guilty being convicted or a guilty person being free from prosecution. However, miscarriages of justice can also be caused at the investigation stage, investigation stage, trial stage, and legal action stage. The state has provided several facilities in minimizing the Miscarriage of Justice which is still lacking because the human resources of law enforcement itself are problematic. The expansion of the concept of State Administrative Decisions as regulated in Article 87 of the Government Administration Law provides an opportunity in the form of filing a lawsuit by victims of miscarriage of justice in the Administrative Court. This is done through an administrative law approach as a primum remedium through testing the authority of law enforcement officers in the Administrative Court. This examination at the Administrative Court can at the same time minimize the occurrence of miscarriages of justice in the future.

\section{References}

[1] Undang-Undang Nomor 8 Tahun 1999 tentang Kitab Undang-Undang Hukum Acara Pidana

[2] Gumilang, T.R., \& Lamada, V. T. M.: Prevention of Miscarriage of Justice in the Implementation of Judges' Tasks. Vol. 7 No. 2, pp. 91-95. Jurnal Hukum Prasada (2020). https://doi.org/10.22225/jhp.7.2.1383.91-95 
[3] Webster, M.: Miscarriage of justice. Merriam-Webster.com Dictionary. https://www.merriam-webster.com/dictionary/miscarriage $\% 20 \mathrm{of} \% 20 \mathrm{justice}$. Accessed 19 Aug 2021.

[4] Marzuki, P.M.,: Pengantar Ilmu Hukum Edisi Revisi. Kencana, Jakarta (2008).

[5] Attamimi, A. H. S.: Teori perundang-undangan Indonesia. A journal from speech ceremony at Law faculty of Universitas Indonesia. Universitas Indonesia Press, Jakarta (1992).

[6] Gumilang, T.R. \& Lamada,V.T.M.: Prevention of Miscarriage of Justice in the Implementation of Judges' Tasks. Jurnal Hukum Persada Vol. 7 No. 2, pp. 91-95.

[7] Kaligis, O.C.: Perlindungan Hukum Atas Hak Asasi Tersangka, Terdakwa Dan Terpidana. Alumni, Bandung (2006).

[8] Walker, C. \& Starmer, K.: Miscarriage of justice a Review of Justice in Error. Blackstone Press Limited (1999).

[9] Rumega, I.W.G.: Hakim Komisaris dan Miscarriage of Justice dalam Sistem Peradilan Pidana. Jurnal Penelitian Hukum De Jure, Volume 19 No.1, pp. 53-68 (2019).

[10] Starr, K.W.: Morality, Community, and the Legal Profession. Wyoming Law Review 5, no. 2, pp 403-416 (2005).

[11] Fachruddin, Irfan.: Pengawasan Peradilan Administrasi Terhadap Tindakan Pemerintah. Alumni. Bandung (2004). 